\title{
22. SUMMARY OF MIDDLE JURASSIC-EARLY CRETACEOUS RADIOLARIAN BIOSTRATIGRAPHY OF SITE 534 (BLAKE-BAHAMA BASIN) AND CORRELATION TO TETHYAN SECTIONS 1
}

\author{
Peter O. Baumgartner, Escuela Centroamericana de Geología, Universidad de Costa Rica
}

\section{INTRODUCTION}

Over 100 samples from Cores 534A-127 through -81 have been examined for radiolarians, which were found to occur abundantly throughout the Jurassic and Early Cretaceous section at Site 534. Excellent preservation in pyrite, however, is restricted to the dark-colored, partly organic-rich claystones and limestones of Cores 126 to 121 and to a few scattered samples from Cores 534A120 through 81 , where both pyrite and quartz preservation occur.

The well-preserved samples of the Callovian-Oxfordian are of high diversity (50-80 species) and show many new forms thus far unknown from the relatively few land samples of that age. A detailed description of the assemblages will be presented elsewhere (Baumgartner, in press).

\section{REVISED RADIOLARIAN ZONATION}

The data from Site 534 samples have been included with a general synthesis of Middle Jurassic to Early Cretaceous radiolarian data in order to obtain a broadly based revision of the preliminary zonation proposed by Baumgartner et al. (1980). The synthesis is based on 235 samples from 43 localities (8 of which are DSDP sites in the Pacific and Atlantic). Presence or absence of 300 morphotypes was recorded, and a selection of 110 species (about 20 of them new) is used for the present zonation. As is our earlier work (Baumgartner et al., 1980), this zonation is based on Unitary Associations (U.A.) (Guex, 1977) and was elaborated by means of a new computer program by Guex and Davaud (1982).

\section{Radiolarian Biostratigraphy of Site 534 (Hole 534A)}

Zone Al. Samples 534A-126-4, $14 \mathrm{~cm}$ to 534A-124-1, $52 \mathrm{~cm}$ are assigned to U.A. 2-4, which define Zone Al. The same succession of U.A. has been found in two sections from the Lombardy Basin in northern Italy and allows for the correlation given in Figure 1. An age of middle to late Callovian is assigned to this Zone on the basis of dinoflagellate and nannofossil data at Site 534 (Sheridan, Gradstein, et al., Site 534 report, this volume). In northern Italy, Callovian aptychi are known from the uppermost Marne a Posidonia (Kalin et al., 1979), which in our sections contain radiolarian assem-

\footnotetext{
${ }^{1}$ Sheridan, R. E., Gradstein, F. M., et al., Init. Repts. DSDP, 76: Washington (U.S. Govt. Printing Office).
}

blages assignable to Zone $\mathrm{AO}$. Thus the base of $\mathrm{A} 1$ must be within the Callovian.

Zone A2. Samples 534A-122-1, $131 \mathrm{~cm}$ to $534 \mathrm{~A}-$ $111-1,12 \mathrm{~cm}$ are assigned to U.A. 5, part of Zone A2. U.A. 5 has been found in several Tethyan sections. This interval includes the entire Oxfordian, according to dinoflagellate data, or the lower Oxfordian, according to nannofossil data (Site 534 report, this volume). In Tethyan sections it appears to represent only the lower part of the Oxfordian, because the entire Zone A2 and at least part of Zone B (U.A. 7 and part of U.A. 8) are Oxfordian, indicated by upper Oxfordian-lowest Kimmeridgian ammonites found above samples assignable to U.A. 8 in Santa Anna, Sicily (Baumgartner et al., 1980). U.A. 6-8 (upper Zone A2 and Zone B) would have to be found between Cores 111 and 106 but could not be identified because of poor radiolarian preservation and/or a possible hiatus in that interval.

Zone C1. Only one sample (534A-106-1, $29 \mathrm{~cm}$ ) can be assigned to U.A. 9. Dinoflagellate data suggest the Kimmeridgian for this level at Site 534, whereas nannofossil data allow for the Oxfordian or Kimmeridgian (Site 534 report, this volume). In Tethyan sections, U.A. 9 (Zone $\mathrm{C} 1$ ) is found in the middle or upper part of the Rosso ad Aptici, which is dated by aptychi and rare ammonites as Kimmeridgian-early Tithonian.

Zone D. One sample (534A-89-2, $47 \mathrm{~cm}$ ) is assigned to U.A. 11. This sample is located immediately above samples assigned to Calpionella Zone B (middle part) and is therefore dated as earliest Berriasian, which is in agreement with nannofossil and dinoflagellate data. In Tethyan sections this U.A. is always found in the basal part of the Maiolica or similar formations and is dated by calpionellids as latest Tithonian (Calpionella Zone B) to latest Berriasian.

Zone $E$. Three samples (from 534A-81-2, $64 \mathrm{~cm}$ to 534A-81-2, $3 \mathrm{~cm}$ ) are assignable to U.A 13 (Zone E1). Dinoflagellate data immediately above this section indicate an age of earliest Valanginian. In Tethyan sections this Zone also first occurs in the basal Valanginian, dated by calpionellids and ammonites, and extends through the lower and middle part of the Valanginian. Zone E2, first occurring in the upper Valanginian, has not been sampled.

\section{CORRELATIONS AND SOME CONCLUSIONS}

The newly defined radiolarian biochronostratigraphic zones allow detailed correlations between Atlantic and Mediterranean Tethyan pelagic sequences. 


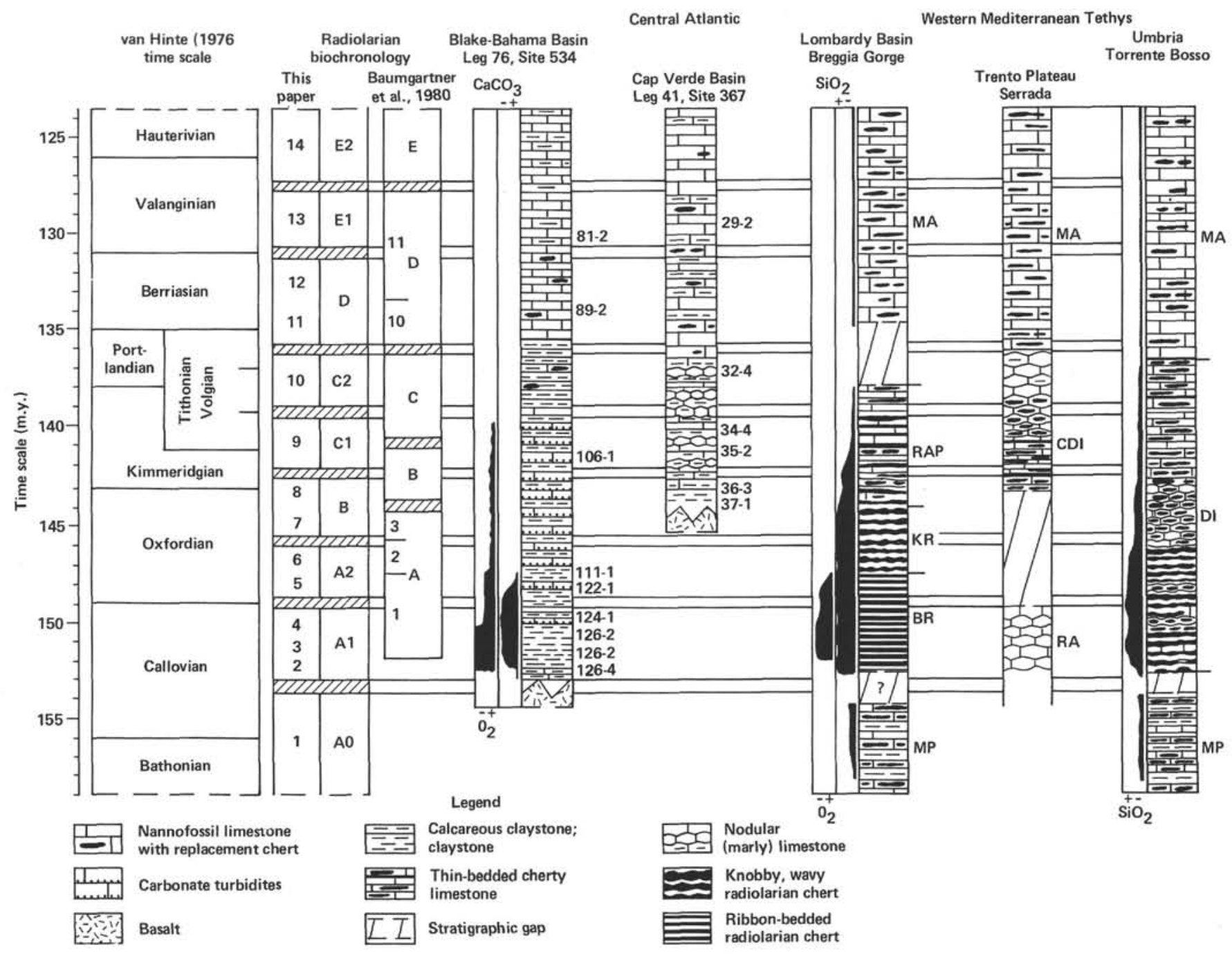

Figure 1. Callovian-Valanginian radiolarian biostratigraphy of Site 534 and chronostratigraphic correlation of Central Atlantic and Tethyan pelagic sequences. (Newly defined Unitary Associations [U.A.] 1-14 and deduced biochronostratigraphic zones A0-E2 are matched to the van Hinte [1976] time scale based on macro- and microfossils co-occurring with radiolarians in the studied sections. For comparison, the zonation of Baum-

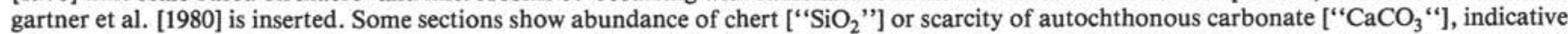
of deposition near or below the calcite compensation depth. The degree of oxygenation of sediments (" $\mathrm{O}_{2}$ ") is inferred from color, presence of pyrite, and so on. Some dated cores and sections are given for the Atlantic sites. The formations are: $\mathrm{CG}=\mathrm{Cat}$ Gap, $\mathrm{BB}=\mathrm{Blake}-\mathrm{Bahama}$, $\mathrm{MP}=$ Marne a Posidonia, $\mathrm{BR}=$ Basal Radiolarite, $\mathrm{RA}=$ Rosso Ammonitico, $\mathrm{DI}=$ Diaspri, $\mathrm{KR}=\mathrm{Knobby}$ Radiolarite, $\mathrm{CDI}=\mathrm{Calcari}$ Diasprigni, RAP = Rosso ad Aptici, and MA = Maiolica. Lithology is based on Sheridan, Gradstein, et al., [Site 534 report, this volume], Lancelot, Seibold, et al. [1978, Site 367 report], E. L. Winterer [personal communication of unpublished field data, 1982, for Torrente Bosso section], and my own data.)

1) The middle to late Callovian-early Oxfordian darkcolored, partly organic-rich claystones and calcareous claystones drilled at Site 534 correlate with the green Basal Radiolarites observed in Lombardy Basin (northern Italy) and other Tethyan, deeply submerged ancient continental margins. There are, however, coeval sequences that do not show any sign of poor oxygenation. The scarcity of carbonate (nannofossils) in the background sediment at Site 534, indicative of a deposition at or even below the local CCD (carbonate compensation depth), correlates with carbonate-poor to carbonate-free radiolarite deposition in the Tethyan basins. It becomes evident that condensed pelagic limestones (Rosso Ammonitico facies) deposited on submarine highs are, in part, time equivalents of the basinal lower radiolarites.
2) During the Oxfordian, deposition at Site 534 was mainly turbiditic and does not greatly resemble the peculiar facies of the Knobby Radiolarites deposited in a well-oxygenated environment at that time in most $\mathrm{Te}$ thyan basins. Most submarine highs show evidence of condensation or erosion-nondeposition (hardgrounds), and evidence for Callovian-Oxfordian deposition is partly or totally lacking (Bernoulli and Jenkyns, 1974). Where carbonate is preserved, pelagic bivalves ("filaments") are abundant.

3) Late Oxfordian-early Kimmeridgian background deposition at Site 534 was still predominantly darkcolored and clay-rich, interrupted by turbidites partly of shallow-water origin. In Tethyan basins well-oxygenated conditions prevailed, and deposition became again slightly calcareous. Nevertheless, during this time sili- 
ceous deposition encroached on most deeper submerged submarine highs and plateaus and had its maximum areal extension. Where carbonates are preserved, the pelagic bivalve facies is succeeded by Saccocoma-rich limestones.

4) In the Tithonian, sedimentation in the Central Atlantic and Western Tethys tended to unify: the upper part of the Cat Gap Formation resembles the coeval upper Rosso ad Aptici of Tethys, in color, type of bedding, and microfacies (Bernoulli, 1972). Nevertheless, Tethyan basinal sections remain far more siliceous than anything cored in the Atlantic.

5) Close to the Jurassic/Cretaceous boundary, in the late to latest Tithonian, sedimentation became even more similar in both areas with the onset of light-colored nannofossil chalk or limestone deposition (BlakeBahama Formation in the Atlantic, Maiolica in Tethys). Again, Tethyan deposition was more siliceous. This type of deposition remained remarkably constant and widespread through the entire Neocomian.

\section{ACCUMULATION RATES}

As would be expected from the largely turbiditic sedimentation at Site 534, Jurassic accumulation rates were, on the whole, four to six times higher here than in any Tethyan radiolarite section $\left(17 \mathrm{~mm} / 10^{3} \mathrm{yr}\right.$. or 4.25 $\mathrm{g} / \mathrm{cm}^{2} / 10^{3} \mathrm{yr}$., with a wet-bulk density of $2.5 \mathrm{~g} / \mathrm{cm}^{3}$ for Cores 534A-126-92 compared to $2.7-4 \mathrm{~mm} / 10^{3} \mathrm{yr}$. or $0.7-1.04 \mathrm{~g} / \mathrm{cm}^{2} / 10^{3} \mathrm{yr}$., with a bulk density of 2.6 $\mathrm{g} / \mathrm{cm}^{3}$, for Tethyan radiolarites.)

Nevertheless, Site 534 radiolarian data suggest important variations of accumulation rates during the Jurassic: in Cores $534 \mathrm{~A}-126$ to -111 , sedimentation rate was as high as $24 \mathrm{~mm} / 10^{3} \mathrm{yr} .\left(6 \mathrm{~g} / \mathrm{cm}^{2} / 10^{3} \mathrm{yr}\right.$.), whereas in Cores $534 \mathrm{~A}-111$ to -106 it averaged only $7 \mathrm{~mm} / 10^{3} \mathrm{yr}$. $\left(1.75 \mathrm{~g} / \mathrm{cm}^{2} / 10^{3} \mathrm{yr}\right.$.), owing to a possible hiatus in that interval. The Neocomian lower Blake-Bahama Formation had an accumulation rate more than two times greater than the Tethyan basinal lower Maiolica $(23$ $\mathrm{mm} / 10^{3} \mathrm{yr}$. or $5.7 \mathrm{~g} / \mathrm{cm}^{2} / 10^{3} \mathrm{yr}$., with a wet-bulk density of $2.4 \mathrm{~g} / \mathrm{cm}^{3}$ for the lower half of Blake-Bahama For- mation compared to $5-10 \mathrm{~mm} / 10^{3} \mathrm{yr}$. or $1.3-2.6 \mathrm{~g} / \mathrm{cm}^{2} /$ $10^{3} \mathrm{yr}$. for various Lombardian and Umbrian sections of the lower Maiolica.)

Because Tethyan radiolarites and Maiolica sections have similar accumulation rates, the change from mainly siliceous to mainly calcareous deposition cannot be explained by an increase of carbonate preservation or production alone. A substantial decrease of silica preservation-production must parallel the explosion of calcareous nannoplankton (Weissert, 1979).

\section{ACKNOWLEDGMENT}

The review of this summary by E. L. Winterer and H. C. Jenkyns is gratefully acknowledged.

\section{REFERENCES}

Baumgartner, P. O., de Wever, P., and Kocher, R., 1980. Correlation of Tethyan Late Jurassic-Early Cretaceous radiolarian events. Cah. Micropaleontol., 2:23-72.

Baumgartner, P. O., in press. A low-latitude Middle Jurassic-Early Cretaceous radiolarian biochronology based on Unitary Associations. Eclogae Geol. Helv.

Bernoulli, D., 1972. North Atlantic and Mediterranean Mesozoic facies: a comparison. In Hollister, C. D., Ewing, J. I., et al., Init. Repts. DSDP, 11: Washington (U.S. Govt. Printing Office), 801-871.

Bernoulli, D., and Jenkyns, H. C., 1974. Alpine, Mediterranean, and Central Atlantic Mesozoic facies in relation to the early evolution of the Tethys. In Dott, R. L., Jr., and Shaver, R. H. (Eds.), Modern and Ancient Geosynclinal Sedimentation, a Symposium. Soc. Econ. Paleontol. Mineral. Spec. Publ., 19:129-160.

Guex, J., 1977. Une nouvelle methode d'analyse biochronologique. Bull. Lab. Geol. Mineral. Geophys. Mus. Geol. Univ. Lausanne, 224:309-322.

Guex, J., and Davaud, E., 1982. Recherche automatiques des association unitaire en biochronologie. Bull. Soc. Vaud. Sci. Mat., 76 (361):53-69.

Kälin, O., Patacca, E., and Renz, O., 1979. Jurassic pelagic deposits from southeastern Tuscany; aspects of sedimentation and new biostratigraphic data. Eclogae Geol. Helv., 72:715-762.

Lancelot, Y., and Seibold, E., et al., 1978. Init. Repts. DSDP, 41: Washington (U.S. Govt. Printing Office).

van Hinte, J. E., 1976. A Jurassic time scale. Bull. Am. Assoc. Pet. Geol., 60:498-516.

Weissert, H. J., 1979. Die Palaeoozeanographie der suedwestlichen Tethys in der Unterkreide. Mitt. Geol. Inst. Eidg. Tech. Hochsch. Univ. Zurich, 226:1-174. 